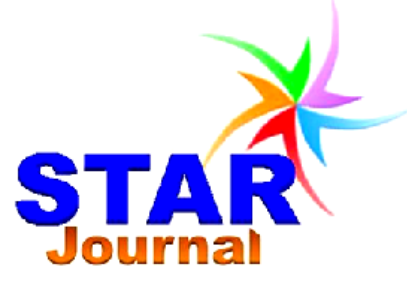

ISSN: 2226-7522(Print) and 2305-3327 (Online) Science, Technology and Arts Research Journal

April-June 2012, 1(2):65-71

www.starjournal.org

Copyright@2012 STAR. All Rights Reserved

Original Research

\title{
Optimal Design of a Standalone Photovoltaic Power Supply System for Air Conditioning Application at Samara University as an Alternative to Diesel Generator Source
}

\author{
Bizuayehu Bogale ${ }^{1}$, Abiy Alemayehu ${ }^{2 *}$ \\ ${ }^{1}$ Department of Electrical Engineering, Samara University, Samara, Ethiopia \\ ${ }^{2}$ Faculty of Engineering, Post Box No: 395, Wollega University, Nekemte, Ethiopia
}

\begin{tabular}{|c|c|}
\hline Abstract & Article Information \\
\hline $\begin{array}{l}\text { The aim of this paper is to optimally design a stand alone photovoltaic power } \\
\text { supply system for air conditioning application at Samara University to be used } \\
\text { as an alternative to diesel generator supply. Samara University is established in } \\
\text { samara town, Afar region and has an average daily radiation of } 6.10 \mathrm{kwh} / \mathrm{m}^{2} \text {, } \\
\text { sun shine duration of about } 10 \text { hours. This condition invites the use of } \\
\text { photovoltaic system as an alternative primary energy source to replace the } \\
\text { existing diesel generator supply system. Therefore in order to use this energy } \\
\text { source for air conditioning application, the cooling load of the building, } 628 \text { tons, } \\
\text { is estimated using Newton's thumb rule. The evaporative air conditioning } \\
\text { system which is sometimes called desert cooler is selected to condition the } \\
\text { estimated cooling load of the dwelling room. The sizing method (numerical } \\
\text { method and HOMER software tools) is complementarily used to design a } \\
\text { standalone photovoltaic power supply system. Finally, the metric value of the } \\
\text { present worth is US } \$ 3,302,066 \text { and its simple payback is } 6.6 \text { years, and this } \\
\text { foreseen that the attractiveness of photovoltaic power system as one of } \\
\text { renewable energy to be used as an alternative to diesel generator in the near } \\
\text { future. }\end{array}$ & $\begin{array}{l}\text { Article History: } \\
\text { Received : 17-02-2012 } \\
\text { Revised : 22-06-2012 } \\
\text { Accepted : 24-06-2012 } \\
\text { Keywords: } \\
\text { Stand Alone Photovoltaic System } \\
\text { Evaporative Air Conditioning System } \\
\text { Diesel Generator } \\
\text { Homer Software Tools } \\
\text { Sizing } \\
{ }^{*} \text { Corresponding Author: } \\
\text { Abiy Alemayehu } \\
\text { E-mail: enate97@gmail.com }\end{array}$ \\
\hline
\end{tabular}

\section{INTRODUCTION}

Samara University is one of governmental institutions established in samara town. Samara is a capital city in the Afar region, and located at $\left(11.45^{\circ} \mathrm{N}\right.$ and $\left.41^{\circ} \mathrm{E}\right)$ (UCBP, 2010). Its climatic condition falls into sunny zone where temperatures range from $27^{\circ} \mathrm{C}$ to $50^{\circ} \mathrm{C}$. As a result, ventilation and air conditioning system is one of the critical issues of the university which are considered to be the functional requirement of the buildings, and when satisfied, affords suitable conditions for living and workers (Arora and Bindra, 2005).Currently, the university is supplied by self-contained diesel station of the town as long as the utility grid will not reach. Using this power supply system to run the air conditioners is not (or will not be) economical and environmentally viable due to increasing fuel cost, need of skilled personnel for maintenance and green house effect that due the gas released. Moreover, the decrement of PV module price and improvement of its efficiency from year to year shows that the PV system can be used as an alternative primary energy source to replace the currently operating system (Wikipedia, 2010).

\section{Solar Energy Potential}

The data obtained shows that tropical regions offer a better solar energy source than at more temperate latitudes. As a whole for Ethiopia the yearly average daily radiation reaching the 
Bizuayehu Bogale \& Abiy Alemayehu

ground is $5.26 \mathrm{kWh} / \mathrm{m}^{2}$ (Bimrew, 2009). On the regional basis of Afar region of the eastern Ethiopia reach to $6.10 \mathrm{kWh} / \mathrm{m}^{2}$ (Getachew and Bjorn, 2009).

Even though in Ethiopia the properly recorded solar radiation data is available only for Addis Ababa (NASA, 2010), the data used in sizing and simulation is based on data recorded for more than 10 years by the NASA Surface meteorology and Solar Energy: RETScreen Data (Ansari and Mokhtar, 2005).

\section{Thermal and Electrical Load}

\section{Thermal Load}

Load has a pronounced effect on solar power generating system design. In this study, the load is an air conditioning unit. In order to save energy bill, initial capital cost and prevent over cooling or under cooling of the dwelling room, the air conditioning unit is selected after the cooling load of the considered building is estimated. Hence, the estimation is made using thumb rule which is popular and widely used load estimation method developed by company based designers (en. wikipedia.org/wiki/air conditioning, 2010).

In this method; direct solar radiation, transmission load through exposed walls, partition walls, roof, ceilings, floors, outdoor air load, appliance, people, and design temperature difference. Cooling load is defined as heat gain (external and internal) to the space to be conditioned. As a result, heat gain is an energy which is commonly expressed in Joules, Btu, Tons or calories (Camargo, 2008; German Energy Society/ Deutsche Gesellschaftfur Sonnenenergie (DGS), 2008).

\section{Electrical Load}

The electrical load of the designed PV power supply system is an evaporative air conditioning unit which is chosen after the comparison of the units with that of refrigerated air conditioning to condition the same dwelling room (Figure 3). The input electrical power to the units determined after its electrical efficiency ratio is assumed i.e. 12 for refrigerated air conditioning and 40 for evaporative air conditioning. This also defined as the ratio of net cooling capacity Btu/hr of the building to electrical efficiency ratio of the units (Ahmed and Sharif, 2007). Figure 3 and Figure 4 shows that the graphical representation of the comparison of both system units in terms of power consumption (kW), and average initial cost expense outside the country.
Sci. Technol. Arts Res. J., April-June 2012, 1(2):65-71

In this study the evaporative air conditioning units (desert coolers) are selected so as to provide a suitable atmospheric condition i.e. conducive to human health with optimal initial cost and energy consumption. Furthermore, the cooling capacity of the system units also shows its capacity to condition the given dwelling room effectively in the hot and dry climatic condition (HOMER, the micropower optimization model; Version 2.8).

The most important condition obtained in this study for the location is that the linearity of the cooling degree days and solar radiation reaching the ground during the day per month. This also shows the viability of solar insolation having the power to run the considered air conditioning system. Cooling degree days are a measure of how much (in degrees), and for how long (in days), outside air temperature was higher than a specific base temperature i.e. the minimum temperature above the ground.

The daily energy consumption of the units can be determined by multiplying its power consumption (kW) with its operating hours of the units per day. Therefore the total energy consumption of the units considered is $2,140 \mathrm{kwh} /$ day. The electrical load calculated thus for is constant for each day of the month. In reality, the size and shape of the load profile will vary from hour to hour and from day to day. Hence, on a daily and hourly basis a $15 \%$ noise level has been added to the calculated load in order to randomize the load profile and make it more realistic. This has scaled up the annual peak load to $362 \mathrm{~kW}$, as can be observed in Figure 6.

Other information which has been input to the calculation program is summarized in Table 1. This information includes the sizes and prices of the solar system components setup which have been obtained from the respective vendors.

\section{The System Sizing and the Setup}

As it was already mentioned before, there is an abundant solar energy at the location, with a daily average amounting to some $6.1 \mathrm{~kW} \mathrm{~h} / \mathrm{m}^{2}$. This resource can be utilized for electric power generation when integrated with PV and could also be used for a standalone power supply system. The capital cost of PV systems has always been the main hindrance to the use of solar energy and also to the promotion of PV technology for large-scale applications especially air conditioning (Shaahid and El-Amin, 2008). However, the new technology of air conditioning 

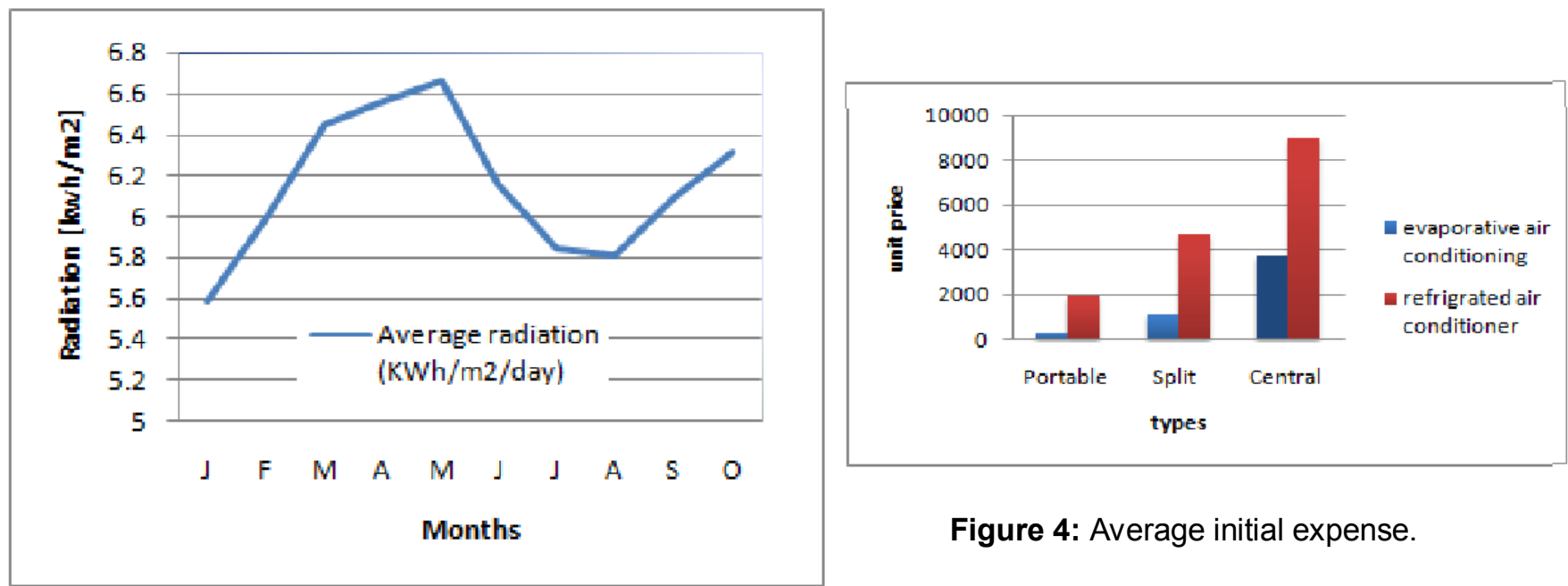

Figure 1: Monthly average daily solar radiation.

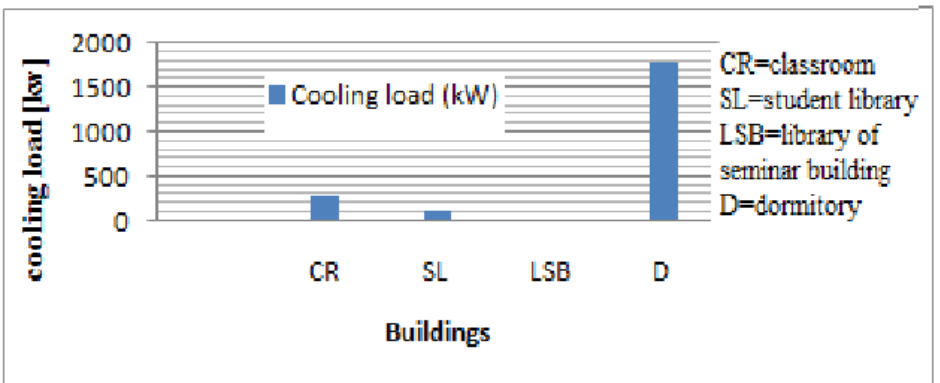

Figure 2: Cooling load of the considered buildings.

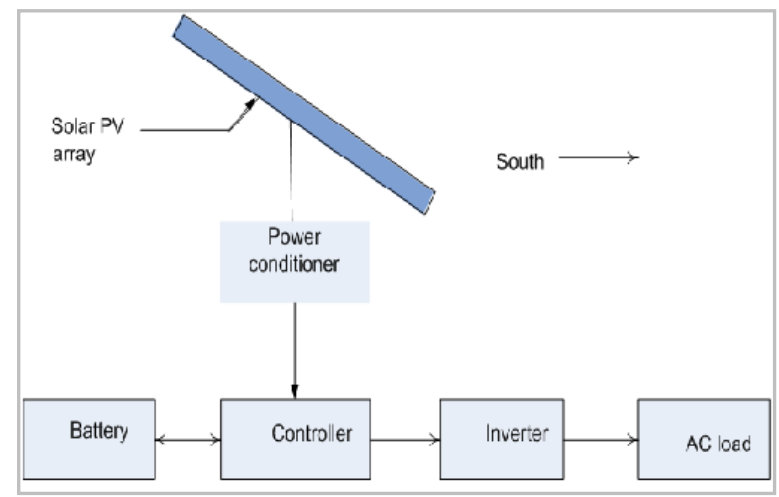

Figure 5: Stand alone PV systems.
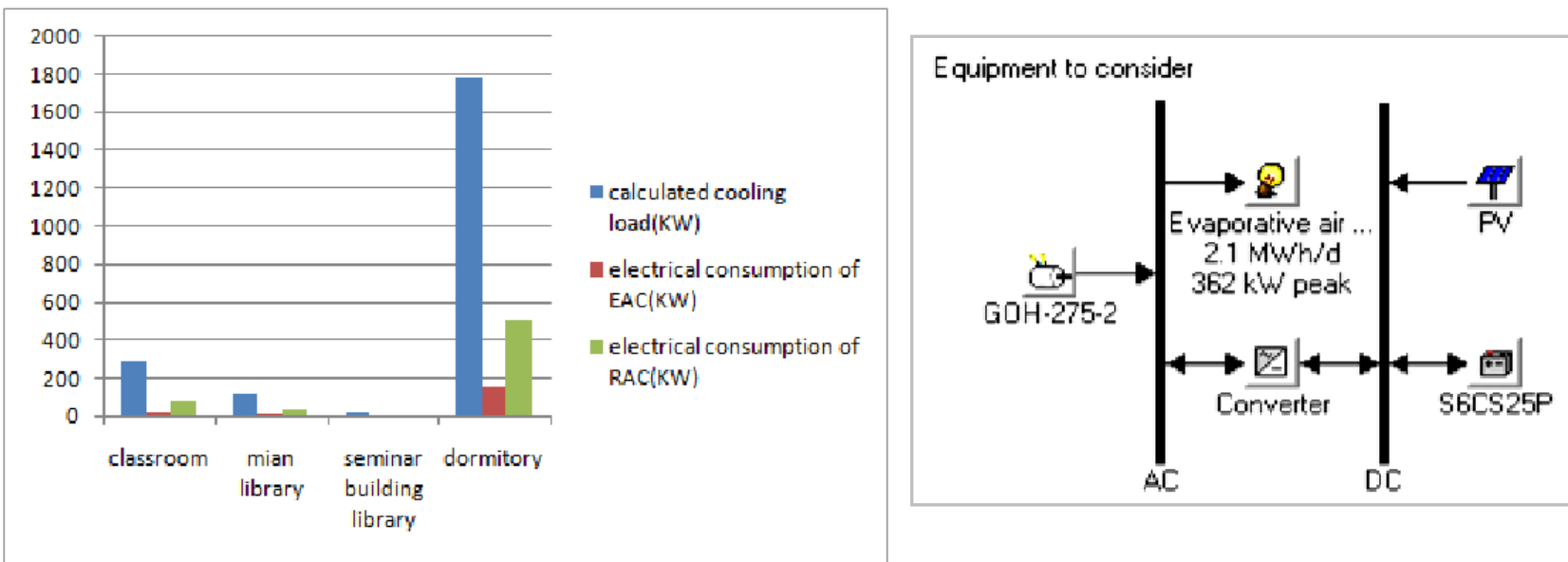

Figure 3: Cooling load \& electric consumption of air conditioning system.

Figure 6: Homer diagram for SAPV system. 
Table 1: Inputs used by the software.

\begin{tabular}{|c|c|c|c|c|}
\hline & PV & $\begin{array}{l}\text { Diesel } \\
\text { Generator }\end{array}$ & $\begin{array}{c}\text { Battery } \\
\text { (Surrette } \\
\text { 6CS25P) }\end{array}$ & Converter \\
\hline Size (kW) & 1 & 1 & $1,156 \mathrm{Ah}$ & 1 \\
\hline Capital (\$) & 3,480 & 288 & 644 & 700 \\
\hline $\begin{array}{l}\text { Replacement } \\
\text { Cost (\$) }\end{array}$ & 3,480 & 210 & 483 & 700 \\
\hline $\begin{array}{l}O \text { and } M \\
\text { Cost }(\$ / y r)\end{array}$ & 0 & $0.025(\$ / h r)$ & 20 & 0 \\
\hline $\begin{array}{l}\text { Sizes } \\
\text { Considered } \\
\text { (kW) }\end{array}$ & $\begin{array}{c}0 \\
100,520 \\
530,540 \\
550,600\end{array}$ & $\begin{array}{r}0,200 \\
292,380\end{array}$ & -- & $\begin{array}{r}0,100 \\
150,200 \\
250,300 \\
350,400\end{array}$ \\
\hline $\begin{array}{l}\text { Quantities } \\
\text { Considered }\end{array}$ & -- & -- & $\begin{array}{r}0,80 \\
140,150 \\
160,180\end{array}$ & -- \\
\hline Life time & 25 years & $60,000 \mathrm{hrs}$ & $\begin{array}{l}9,645 \\
\text { kWh }\end{array}$ & 15 years \\
\hline
\end{tabular}

(i.e. evaporative air conditioning) has come to the market which is energy efficient and cost effective, and it can also be supplied by PV the PV systems could also be competitive where the rapid increase in the price of the oil considered (Screen data/ Document generated on Jun 27 15:03:55 EDT 2010).

In advance the technology investment in the production facilities and increasing fuel prices, solar power is becoming a serious candidate in the electricity market. The consumer always needs a constant and reliable power supply system with affordable cost. However the power generation from solar system is not constant, therefore the battery bank has included storing energy when excess solar energy is available and releases it when needed so as to ensure a constant power system.

In this study the availability of solar radiation at samara site and the new technology of air conditioning are investigated and the economic comparison of the designed stand alone PV power supply system with currently operating system is also done. system because it only consumes the electrical energy only for air circulation and water pumping. Despite its high initial capital cost,

The schematic diagram of the stand alone PV power supply system is shown in Figure 5 and its representation by HOMER is also shown in fig.6. The genset source has integrated only for economic evaluation.

\section{RESULTS AND DISCUSSION}

An important element of any power generating system is the load which has a pronounced effect on system design. Here the load is an air conditioning unit. The electric consumption of this load is determined after the cooling load of the dwelling room to be conditioned is estimated (http://en.wikipedia.org/wiki/air conditioning, 2010). Therefore, the estimated cooling load is $7,535,221.4 \mathrm{Btu} / \mathrm{hr}$ and to remove this load from the space where the electrical consumption of the refrigerated air conditioning is $627.3 \mathrm{~kW}$, the consumption of evaporative air conditioning is 188.2kW. The evaporative air conditioning consumes only $30 \%$ of energy consumed by that of refrigerated air conditioning. 


\section{Bizuayehu Bogale \& Abiy Alemayehu}

The selection and sizing of the components of solar power system has been done using numerical method and NREL's HOMER (hybrid optimization model for electric renewable) software complementarily. HOMER is a simplified optimization model, which performs hundreds or thousands of hourly simulations (to ensure best possible matching between supply and demand) in order to design the optimum system (Shaahid and El-Amin, 2008). It uses life cycle cost to rank order these systems. The software performs automatic sensitivity analyses to account for the sensitivity of the system design.

The results are displayed in either of two forms; an overall form in which the top-ranked system configurations are listed according to their net present cost and in a categorized form; where only the least-cost system configuration is considered for each possible system type. Table 2 shows a list of the possible combinations of system components in the overall form. The table has been generated based on inputs selected from the input summary table (Table 1 ): $0.8 \$ / l$ for
Sci. Technol. Arts Res. J., April-June 2012, 1(2):65-71

diesel price (http://www.solarbuzz.com/ Moduleprices.htm, Aug_2010). The diesel price is the current price for diesel oil in the country. Interest rates are assumed to be $4 \%$ and project lifetime is 25 years.

Looking at a few of the system setups listed, we find the following interesting results. The most cost effective system i.e. having the lowest net present cost is the PV-battery-converter setup, where the generator operates using a load following strategy (a dispatch strategy whereby the renewable power output to serve the primary load and any surplus electrical production goes toward the lower-priority objectives). For this setup, the total net present cost (NPC) is $\$ 3,666,051$, the cost of energy (COE) is 0.323 $\$ / \mathrm{kWh}$ and also the contribution of renewable resources is $100 \%$ to the energy supply. The average monthly electric production of this setup is given in Figure 7 and the cost breakdown, illustrated by a pie-chart, for this setup, is also given in Figure 8.

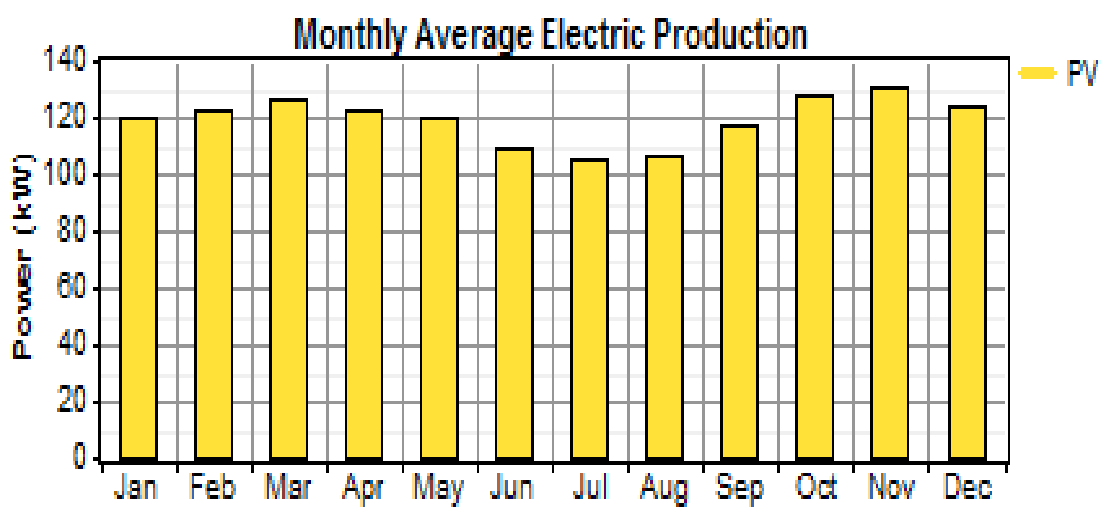

Figure 7: Power generated by photovoltaic system.

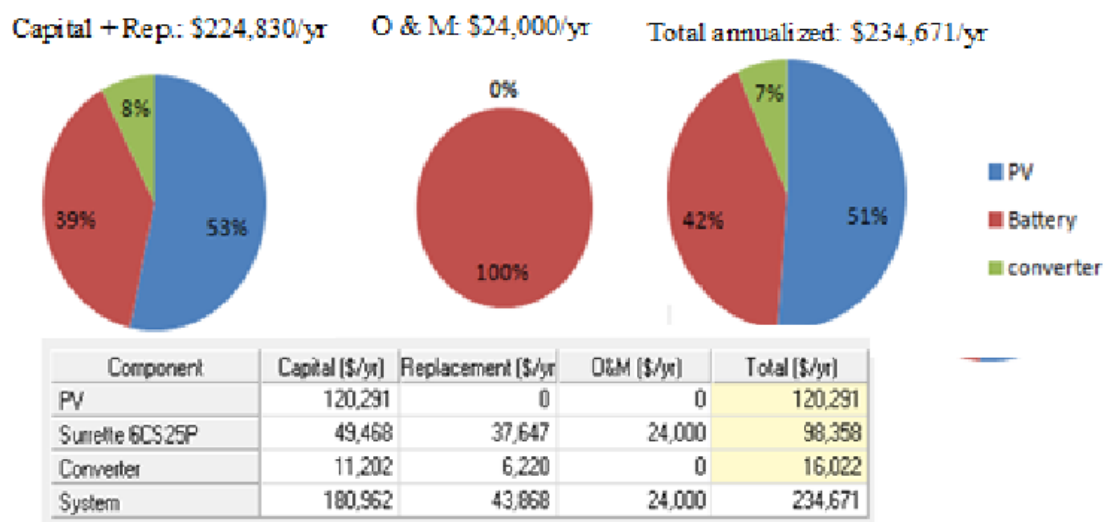

Figure 8: Cost summary of standalone PV power system. 
Table 2: Overall optimization results according to the NPC.

\begin{tabular}{|c|c|c|c|c|c|c|c|c|c|}
\hline $\begin{array}{l}\text { PV } \\
(\mathrm{KW})\end{array}$ & $\begin{array}{l}\text { Gen } \\
\text { (KW) }\end{array}$ & Battery & $\begin{array}{c}\text { Inverter } \\
\text { (KW) }\end{array}$ & $\begin{array}{l}\text { capital } \\
\text { cost }(\$)\end{array}$ & NTC (\$) & $\begin{array}{c}\text { COE } \\
\text { (\$/KWh) }\end{array}$ & $\begin{array}{c}\text { Renewable } \\
\text { Fraction }\end{array}$ & $\begin{array}{l}\text { Diesel } \\
\text { (\$/yr) }\end{array}$ & $\begin{array}{c}\text { Gen } \\
\text { hours } \\
\text { (hr/yr) }\end{array}$ \\
\hline 540 & - & 1,200 & 250 & $2,827,000$ & $3,666,051$ & 0.323 & 1 & - & - \\
\hline 520 & - & 1,280 & 250 & $2,808,920$ & $3,698,888$ & 0.326 & 1 & - & - \\
\hline 550 & 380 & 1,200 & 300 & $3,006,240$ & $4,200,306$ & 0.345 & 0.94 & 24,538 & 393 \\
\hline 600 & 380 & 1,280 & 300 & $3,231,760$ & $4,283,414$ & 0.352 & 0.97 & 11,695 & 189 \\
\hline 600 & 380 & 1,440 & 300 & $3,334,800$ & $4,411,491$ & 0.363 & 0.98 & 06,592 & 108 \\
\hline 100 & 380 & - & 100 & 527,440 & $5,849,272$ & 0.481 & - & 356,649 & 5,227 \\
\hline 100 & 380 & - & 150 & 562,440 & $5,899,329$ & 0.485 & - & 356,649 & 5,227 \\
\hline- & 380 & 640 & 100 & 591,600 & $6,513,526$ & 0.536 & - & 369,070 & 5,447 \\
\hline- & 380 & 640 & 150 & 626,600 & $6,562,532$ & 0.540 & - & 369,013 & 5,445 \\
\hline 520 & 380 & - & 200 & $2,059,040$ & $6,907,650$ & 0.568 & 0.10 & 321,626 & 4,844 \\
\hline 520 & 380 & - & 250 & $2,094,040$ & $6,933,183$ & 0.57 & 0.11 & 320,035 & 4,817 \\
\hline- & 380 & - & - & 109,440 & $6,968,115$ & 0.573 & - & 460,330 & 6,830 \\
\hline
\end{tabular}

Table 3: Categorized optimization results.

\begin{tabular}{|c|c|c|c|c|c|c|c|c|c|c|c|}
\hline $\begin{array}{l}\mathrm{PV} \\
\mathrm{kW})\end{array}$ & $\begin{array}{l}\text { Gen } \\
(\mathrm{kW})\end{array}$ & S6CS25P & $\begin{array}{l}\text { Conv. } \\
(\mathrm{kW})\end{array}$ & $\begin{array}{l}\text { Intial } \\
\text { Captal }\end{array}$ & $\begin{array}{l}\text { Operating } \\
\text { Cost }(\$ / y r)\end{array}$ & $\begin{array}{l}\text { Total } \\
\text { NPC }\end{array}$ & $\begin{array}{c}\text { COE } \\
(\$ / \mathrm{kWh})\end{array}$ & $\begin{array}{l}\text { Ren. } \\
\text { Frac. }\end{array}$ & \begin{tabular}{|l|} 
Capacty \\
Shortage
\end{tabular} & $\begin{array}{c}\text { Diesel } \\
\text { (L) }\end{array}$ & $\begin{array}{l}\text { Gen } \\
\text { (hrs) }\end{array}$ \\
\hline 540 & & 1200 & 250 & $\$ 2,827,000$ & 53.709 & $\$ 3,666,051$ & 0.323 & 1.00 & 0.09 & & \\
\hline 550 & 380 & 1200 & 300 & $\$ 3,006,240$ & 76,434 & $\$ 4,200,306$ & 0.345 & 0.94 & 0.00 & 24.538 & 393 \\
\hline \multirow[t]{3}{*}{100} & 380 & & 100 & $\$ 527,440$ & 340,661 & $\$ 5,849,272$ & 0.481 & 0.00 & 0.00 & 356,649 & 5.227 \\
\hline & 380 & 640 & 100 & $\$ 591,600$ & 379.074 & $\$ 6.513 .526$ & 0.536 & 0.00 & 0.00 & 369.070 & 5.447 \\
\hline & 380 & & & $\$ 109,440$ & 439.037 & $\$ 6,968,115$ & 0.573 & 0.00 & 0.00 & 460,330 & 6.830 \\
\hline
\end{tabular}

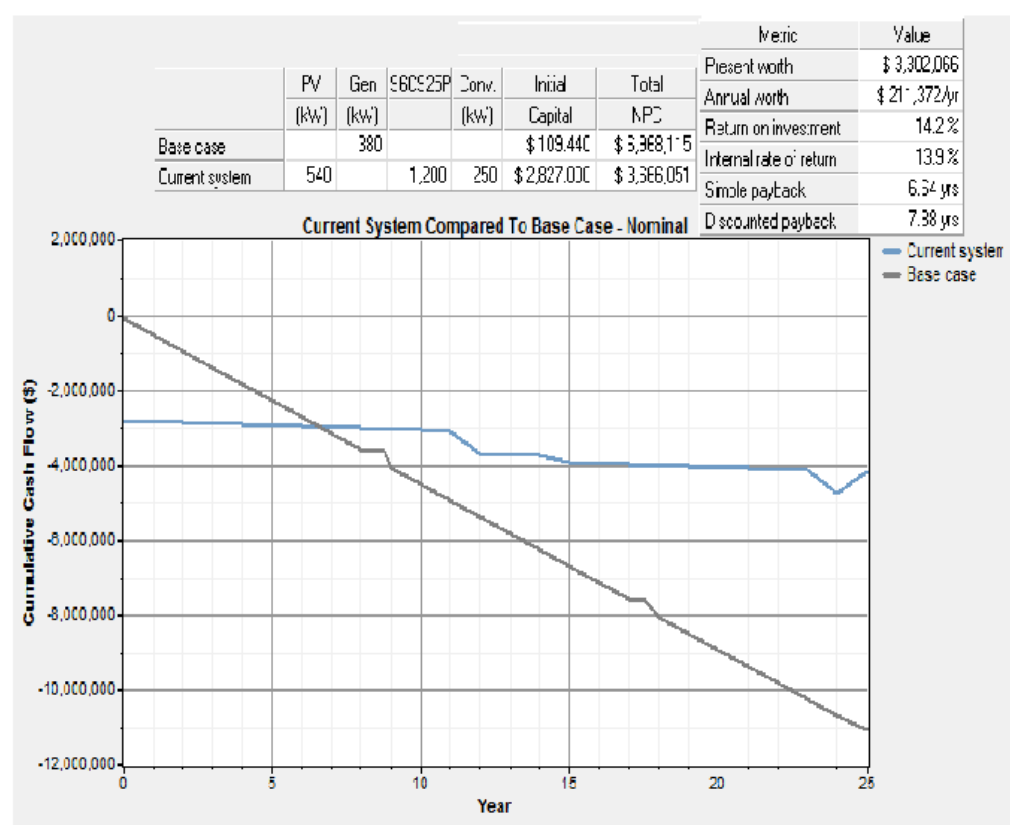

Figure 9: Economic comparisons of SAPV system and Diesel-only system. 


\section{Bizuayehu Bogale \& Abiy Alemayehu}

The result of optimization, in a categorized form, is given in Table 3; they are ranked according to the NPC but in such a way that the least-cost system is considered for each type of system. Fig.9 shows that the metric value of the present worth US\$ 3,302,066 is the difference between the net present cost of the diesel only (base case) system and the stand alone PV (current system) system. The positive value of present worth indicates that the PV system saves money over the project lifetime compared to the diesel only system. As a result, the SAPV system compares favourably as an investment option with the diesel-only system.

\section{CONCLUSIONS}

The study indicates that the location being gifted with considerable monthly average daily global solar radiation intensity (5.58-6.66 $\mathrm{kWh} / \mathrm{m} 2$ ), is a prospective candidate for deployment of PV power systems. Therefore the PV system has the power to run an evaporative air conditioning system effectively. In order to save the energy bill and initial capital cost of this air conditioning system, the cooling load of the considered building has been estimated. The sizing results suggest that HOMER software is a powerful tool that gives the optimum and cost effective systems according to hourly demand. The cost of generating energy (COE) from the stand alone PV system has been found to be $0.323 \mathrm{US} \$ / \mathrm{kWh}$ (assuming diesel fuel price of $0.8 \$ / 1$ and max. capacity shortage of $10 \%$ ). Henceforward, according to the optimization result a stand alone PV system with battery storage (renewable fraction 1.0) is a better solution. This shows, a great potential of Solar (PV) power system in future as one of renewable energy technology alternatives for diesel power generation.

\section{REFERENCES}

Ahmed, D., Sharif A.R.H. (2007). Design and development of photovoltaic power system for greenhouse cooling. American Journal of Applied Science 4(6): 386-389.

Arora, S.P., Bindra (2005). A text book of building construction including Engineering materials, for engineering students, fifth edition, pp. 1-21.

Bimrew Tamrat (2007). Comparative Analysis of Feasibility of Solar PV, Wind and Micro Hydro Power Generation for Rural Electrification in the selected sites of Ethiopia. Master thesis, Addis Ababa University, 2007.
Sci. Technol. Arts Res. J., April-June 2012, 1(2):65-71

Ansari, F.A., Mokhtar, A.S., Abbas, K.A., Adam, N.M A. (2005). Simple Approach for Building Cooling Load Estimation. American Journal of Environmental Sciences 1(3): 209-212.

Getachew Bekele., Bjorn Palm. (2009). Feasibility of a standalone solar wind hybrid electric energy supply system, for application in Ethiopia," Stockholm, Sweden.

http://en.wikipedia.org/wiki/airconditioning,down loaded 1 August 2010.

http://www.nrel.gov/homer, HOMER, the micropower optimization model; Version 2.8

http://www.solarbuzz.com/Moduleprices.htm,Aug_2010

http:en.wikipedia.org/wiki/Air_conditioning\#Air_conditio ning_application,on 6 July $\overline{2} 010$ at 16:50

http:wikipedia.org/solar air conditioning, on 6 July 2010 at 12:00

http:www.larc@eos.nasa.gov/Nasa surface metrology and solar energy: RETScreen data/ Document generated.

Josè Rui Camargo. (2008). Evaporative cooling: water for thermal comfort. An Interdisciplinary Journal Of Applied Science 3(2): 1980-993X.

Planning and installing, photovoltaic systems: a guide for installers, architects, and engineers, $2^{\text {nd }}$ edition. German Energy Society/ Deutsche Gesellschaft fur Sonnenenergie (DGS), 2008.

Shaahid, S.M., El-Amin, I. (2008). Technoeconomic evaluation of off-grid hybrid photovoltaic-dieselbattery power systems for rural electrification in Saudi Arabia -A way forward for sustainable development. Renewable and Sustainable Energy Reviews 13(3):625-633.

University capacity building program (2010, April): http/ www.ucbp.ethiopia.com /e508. 